Original Research Paper

\title{
Pelatihan Pembuatan Media Pembelajaran Menggunakan Canva bagi Guru SMPN 1 Tegalampel Bondowoso
}

\author{
Riza Yuli Rusdiana ${ }^{1}$, Widya Kristiyanti Putri ${ }^{1}$, Vega Kartika Sari ${ }^{1 *}$ \\ ${ }^{I}$ Department of Agronomy, Jember University, Jember, Indonesia;
}

https://doi.org/10.29303/jpmpi.v3i2.952

Sitasi: Rusdiana, R. Y., Putri, W. K \& Sari, V. K. (2021). Pelatihan Pembuatan Media Pembelajaran Menggunakan Canva bagi Guru SMPN 1 Tegalampel Bondowoso. Jurnal Pengabdian Magister Pendidikan IPA, 4(3)

Article history
Received: 28 Agustus 2021
Revised: 10 September 2021
Accepted: 13 September 2021
*Corresponding Author: Vega
Kartika Sari, Department of
Agronomy, Jember University,
Indonesia;
Email: vegakartikas@unej.ac.id

\begin{abstract}
The use of learning media by utilizing technology is very important needed during a pandemic. Learning media can be in the form of visual, audio, and audio visual. Attractive learning media can create memorable and easier-to-understand learning activities. Canva is a graphic design application that helps users to create various types of creative materials online. Using Canva as a learning medium can make it easier for teachers to design learning media. Almost all teachers at SMPN 1 Tegalampel have not been able to make video-based learning media so that the delivery of material to students is still low. This activity aims to provide training in making learning media using Canva for teachers at SMPN 1 Tegalampel, Bondowoso. The training activities were carried out in several stages, namely socialization, practice, and evaluation. The results of the activity showed that the training participants got an increase in knowledge and skills related to learning media using the Canva application.
\end{abstract}

Keywords: Learning Media; Canva; Teachers

\section{Pendahuluan}

Proses pembelajaran di sekolah tidak lepas dari pendekatan, metode, dan media yang digunakan dalam proses pembelajaran. Ketepatan metode ataupun media yang digunakan akan sangat mempengaruhi efektifitas dan keberhasilan proses pembelajaran. Tolak ukur dari keberhasilan proses pembelajaran ialah dari capaian pembelajaran. Siswa menjadi lebih mudah memahami atau menguasai matari pembelajaran. Menurut Sinsuw dan Sambul (2017), perkembangan kurikulum perlu ditunjang dengan kemampuan guru dalam dalam mengembangkan media pembelajaran yang efektif untuk mencapai tujuan pembelajaran dan meningkatkan kualitas capaian pembelajaran yang diharapkan. Media pembelajaran dengan memanfaatkan teknologi informasi akan membawa situasi belajar yang semula learning with effort menjadi learning with fun.
Sekolah Menengah Pertama Negeri 1 Tegalampel berada di wilayah administratif Kabupaten Bondowoso. Lokasi sekolah berada Kecamatan Tegalampel, Kabupaten Bondowoso. Sekolah ini berada di pinggiran kota, namun demikian sekolah ini memiliki cukup banyak torehan prestasi di skala kabupaten. Jumlah guru di sekolah ini berjumlah 27 orang, yang sebagian besar berpendidikan akhir Strata 1 Jurusan Pendidikan. Menurut Wartomo (2016), Guru dengan berbagai kompetensinya, mempunyai peranan sebagai sumber belajar, fasilitator, motivator dan lainnya. Peranan-peranan tersebut tidak bisa dilepaskan dalam rangka pengembangan kecerdasan baik intelektual, emosional dan spiritual.

Tuntutan guru sebagai pengajar untuk dapat menyampaikan materi-materi pembelajaran di masa pendemi Covid-19 merupakan tantangan besar, salah satunya kurangnya motivasi siswa dalam 
menyimak pembelajaran daring (Cahyani, 2020). Motivasi belajar siswa penting artinya karena berpengaruh dalam keberhasilan pembelajaran (Resmini dkk, 2021). Selama pendemi kegiatan belajar mengajar di SMPN 1 Tegalampel dilakukan secara daring. Aplikasi yang digunakan ialah Google Classroom dan WhatsApp untuk memberikan tugas dan menyampaikan file materi ajar.

Penggunaan media pembelajaran dengan memanfaatkan teknologi sangat penting diperlukan di masa pendemi Covid-19. Media pembelajaran dapat berupa visual, audio, dan audio visual. Video merupakan media audio visual, dapat membantu siswa untuk berpikir konkrit, logis dan menciptakan kegiatan pembelajaran yang imajinatif, kreatif serta berkesan (Febrianto dkk, 2020). Hampir seluruh guru di SMPN 1 Tegalampel belum mampu membuat media pembelajaran berbasis video sehingga ketersampaian materi ke siswa masih rendah. Fasilitas wifi dan ruang komputer/ TIK di SMPN 1 Tegalampel diharapkan dapat dimanfaatkan maksimal oleh para guru dengan membuat video pembelajaran.

Canva merupakan aplikasi desain grafis yang membantu pengguna untuk membuat berbagai jenis material kreatif secara online. Menu desain Canva meliputi membuat buku online atau e-modul, persentasi, video persentasi, poster dan lain-lain. Canva dapat digunakan di laptop melalui web browser dan handphone (iOS dan Android) melalui aplikasi Canva. Tersedianya template dengan beragam tema yang sangat menarik menajdikan Canva banyak digemari dan memudahkan pengguna pemula. Menurut Tanjung dan Faiza (2019), penggunaan Canva sebagai media pembelajaran dapat mempermudah dan menghemat waktu guru dalam mendesain media pembelajaran dan menjelaskan materi pelajaran. Aplikasi Canva dapat memudahkan siswa dalam memahami pelajaran dikarenakan tampilan teks, animasi, grafik dan lain-lain sesuai dengan tampilan yang diinginkan dan membuat siswa fokus memperhatikan pelajaran karena tampilannya menarik.

Berdasarkan paparan diatas, media pembelajaran interaktif berbasis video menjadi solusi tim kepada mitra. Keterampilan membuat video ditengah situasi pendemi Covid-19 akan memudahkan guru dalam menyampaikan pesanpesan dalam proses pembelajaran dan siswa dapat memutar ulang materi-materi pelajaran. Sejalan menurut Setiawan dan Jatmikowati (2021) bahwa di masa pandemi Covid-19, guru harus mampu berevolusi dan berinovasi dalam melaksanakan kegiatan pembelajaran. Tim dan mitra sepakat untuk mengadakan pelatihan pembuatan media pembelajaran berbasis video menggunakan aplikasi Canva bagi guru-guru SMPN 1 Tegalampel.

\section{Metode}

Pelaksanaan kegiatan dilaksanakan secara luring di ruang TIK SMP Negeri 1 Tegalampel Bondowoso. Pelaksanaan kegiatan pelatihan dibagi menjadi beberapa tahapan meliputi persiapan awal, sosialisasi/ penyuluhan, praktek dan evaluasi kegiatan. Pretest dan postest juga diberikan kepada peserta pelatihan guna mengetahui kemampuan awal dan akhir guru SMP Negeri 1 Tegalampel terkait materi yang akan diberikan. Uraian dari masing-masing kegiatan tersebut, meliputi:

1. Perencanaan

- Tim berkoordinasi dengan pihak Badan Kesatuan Bangsa dan Politik (Bakesbangpol) Kabupaten Bondowoso, Dinas Pendidikan dan Kebudayaan Kabupaten Bondowoso dan SMPN 1 Tegalampel untuk meminta ijin mengadakan kegiatan pengabdian kepada masyarakat.

- Tim berkoordinasi dengan Kepala Sekolah SMPN 1 Tegalampel untuk menentukan waktu pelatihan dan sarana prasarana yang dibutuhkan selama kegiatan.

- Membentuk tim kerja untuk pelaksanaan kegiatan yang terdiri dari dosen dan mahasiswa.

- Membuat kuisioner pretest dan postest

- Membuat persentasi dari berbagai sumber referensi untuk materi pelatihan

2. Pelaksanaan

Kegiatan pelatihan dilakukan dengan metode ceramah interaktif dan praktik langsung menggunakan wifi dan komputer yang tersedia di ruang TIK. Sebelum pemaparan materi, guru-guru diberikan kuisioner dan soal pretest yang berisi soal-soal terkait Canva. Selanjutnya pemaparan materi, materi yang akan disampaikan berupa pengenalan aplikasi Canva; cara register di Canva; fitur-fitur yang 
tersedia dalam pembuatan video menggunakan Canva dan praktik pembuatan video pembelajaran menggunakan Canva. Pada sesi terakhir, guru-guru diberikan kuisioner dan postest yang berisi soal sama dengan pretest. Hal ini bertujuan untuk mengetahui efektifitas dari kegiatan pelatihan.

3. Evaluasi

Evaluasi tertulis dalam bentuk pre/post test dilakukan pada sesi awal dan akhir kegiatan untuk mengetahui pemahaman guru SMPN 1 Tegalampel terhadap materi yang diberikan.

Dalam pelaksanaan kegiatan ini, tim melakukan metode pendekatan persuasif dan edukatif. Persuasif, yaitu pendekatan yang bersifat himbauan, ajakan, dan dukungan tanpa ada unsur paksaan bagi peserta untuk berperan aktif dalam kegiatan ini. Edukatif, yaitu pendekatan sosialisasi, pelatihan, dan pendampingan sebagai sarana transfer ilmu pengetahuan dan keterampilan/ softskill untuk peserta.

\section{Hasil dan Pembahasan}

Permasalahan yang dihadapi oleh mitra yaitu SMPN 1 Tegalampel diantaranya: (1) belum ada guru di SMPN 1 Tegalsampel yang memanfaatkan media pembelajaran video pada proses pembelajarannya; (2) belum ada guru yang mengikuti pelatihan pembuatan media pembelajaran berbasis video; (3) sebagian guru belum memiliki laptop, sehingga selama ini proses pembelajaran menggunakan media handphone hanya memanfaatkan aplikasi WhatsApp; dan (4) minimnya kreatifitas dalam memanfaatkan aplikasi desain grafis yang tersedia di media handphone.

Berdasarkan permasalahan mitra yang sudah dipaparkan, tim pengusul dan mitra telah sepakat bahwa update kompetensi guru dalam hal kemampuan membuat video pembelajaran merupakan persoalan prioritas yang harus diselesaikan baik dikondisi COVID 19 maupun sesudah COVID 19 berakhir. Update kompetensi dilakukan melalui pelatihan pembuatan media pembelajaran berbasis video menggunakan aplikasi Canva bagi guru SMPN 1 Tegalampel.

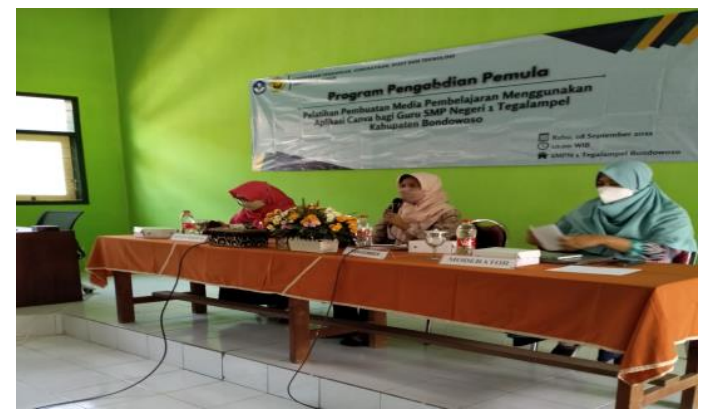

Gambar 1. Sosialisasi Canva bagi Guru SMP N 1 Tegalampel Bondowoso

Kegiatan pelatihan dilaksanakan di Ruang TIK SMP Negeri 1 Tegalampel. Kegiatan diawali dengan sosialisasi tentang Canva (Gambar 1). Bapak ibu guru yang mengikuti pelatihan sebanyak 16 orang. Sebelum dan sesudah kegiatan, peserta pelatihan diminta mengisi kuisioner persepsi melalui link google form yang berisi pernyataanpernyataan: (1) Saya mengetahui kegunaan aplikasi Canva; (2) Saya dapat membuat media pembelajaran dengan menggunakan Canva; (3) Saya mengetahui fitur-fitur (audio, background, record video dsb) yang tersedia di Canva; (4) Saya dapat menggunakan fitur-fitur (audio, background, record video dsb) yang tersedia di Canva; dan (5) Media pembelajaran yang dihasilkan dengan Canva menarik dan efektif. Kegiatan setelah sosialisasi ialah praktek membuat media pembelajaran menggunakan komputer PC yang disediakan pihak sekolah (Gambar 2).

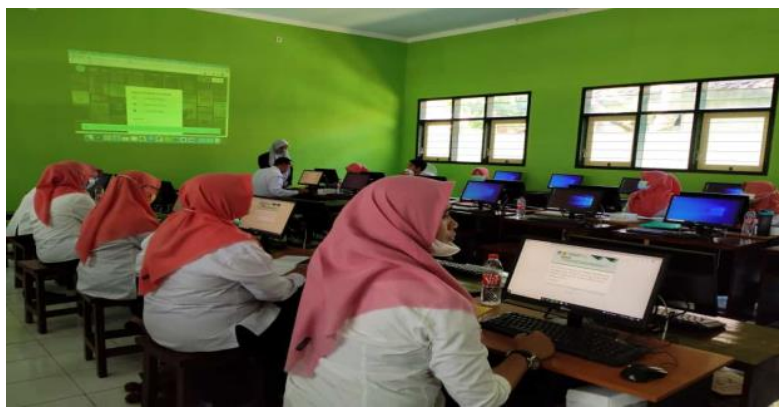

Gambar 2. Praktek Canva di Ruang TIK SMP N 1 Tegalampel Bondowoso

Dari 16 peserta yang mengikuti pelatihan, 13 peserta mengisi kuisioner pra pelatihan dan pasca pelatihan. Hasil persepsi responden dari lima pernyataan pada kuisioner ditampilkan pada Gambar 3. Peserta mengetahui kegunaan aplikasi Canva sebelum pelatihan sebanyak 7 guru dan 
setelah mengikuti pelatihan seluruh peserta mengetahui kegunaan aplikasi Canva sebagai aplikasi desain grafis terutama untuk membuat media pembelajaran. Sebelum pelatihan, 3 guru menyatakan mampu membuat media pembelajaran dengan menggunakan Canva dan setelah mengikuti kegiatan terdapat kenaikan 10 guru dari sebelumnya. Selain itu pengetahuan dan keterampilan dalam menggunakan fitur-fitur yang tersedia pada aplikasi terdapat kenaikan signifikan dari sebelum pelatihan.

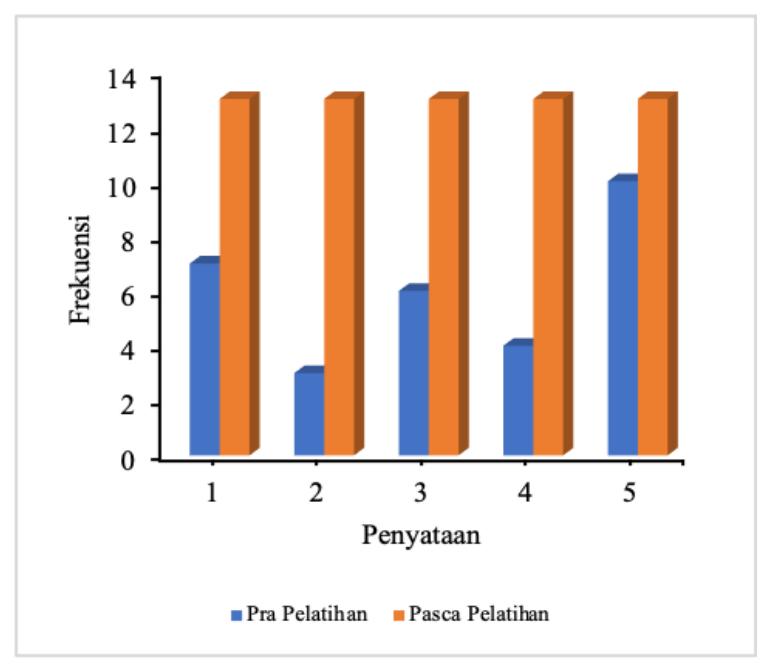

Gambar 3. Hasil Kuisioner Persepsi Pengetahuan dan Keterampilan Responden

Deskriptif dari data pretest dan postest disajikan pada Tabel 1. Nilai pretest paling rendah sebesar 20 dan postest 60 , namun kedua tes tersebut memiliki nilai maksimal yang sama. Rata-rata nilai pretest sebesar 64. Nilai tersebut lebih rendah dibandingkan rata-rata nilai yang diperoleh peserta pada saat postest sebesar 87.5. Hasil data pretest lebih beragam dibandingkan data postest.

Tabel 1. Statistika Deskriptif Pretest dan Postest

\begin{tabular}{lcccc}
\hline Variabel & Min & Max & Mean & $\begin{array}{c}\text { Std. } \\
\text { Deviation }\end{array}$ \\
\hline Pretest & 20 & 100 & 64.375 & 22.2017 \\
Postest & 60 & 100 & 87.500 & 12.383 \\
\hline
\end{tabular}

Nilai pretest ditentukan melalui nilai hasil mini quiz yang diberikan sebelum pelatihan Canva dilakukan dan nilai postest merupakan nilai hasil mini quiz setelah guru-guru menerima pelatihan Canva. Uji paired t-test antara pretest dan postest dilakukan untuk mengetahui perbedaan pengetahuan antara sebelum dan sesudah pelatihan.

Tabel 2. Hasil Uji Perbandingan Pretest dan Postest

\begin{tabular}{llcc}
\hline & df & t-statistics & P-value \\
\hline Post - Pre & 15 & 5.201 & 0.000 \\
\hline
\end{tabular}

Tabel 2 menunjukkan hasil paired t-test. Nilai tstatistics sebesar 5.201 lebih besar dibandingkan $\mathrm{t}_{0.025 ; 15}$ sebesar 2.49 dan p-value lebih kecil dibandingkan 0.05 sehingga dapat dinyatakan terdapat perbedaan secara statistik antara nilai pretest dan postest. Hal ini dapat disimpulkan jika kegiatan pengabdian masyarakat pada guru-guru SMPN 1 Tegalampel melalui pelatihan Canva memiliki tingkat efektifitas yang signifikan. Guruguru yang mengikuti pelatihan mendapatkan informasi pengetahuan dan keterampilan terkait media pembelajaran menggunakan aplikasi Canva.

Peserta setelah mendapatkan pelatihan memiliki kompetensi dalam membuat video pembelajaran yang menarik dan interaktif. Peserta juga menerapkan canva dalam pembuatan media pembelajaran pada mata pelajaran yang diampu.

\section{Kesimpulan}

Berdasarkan hasil pelaksanaan kegiatan yang meliputi sosialisasi, praktek, dan evaluasi pembuatan media pembelajaran menggunakan canva maka dapat disimpulkan bahwa melalui kegiatan ini guru SMPN 1 Tegalampel selaku peserta mendapatkan tambahan pengetahuan dan keterampilan tentang pembuatan media pembelajaran dengan canva, peserta juga antusias selama kegiatan dan langsung menerapkan menggunakan canva untuk mata pelajaran yang diampu.

\section{Ucapan Terima Kasih}

Penulis mengucapkan terima kasih kepada LP2M Universitas Jember yang telah memberi dukungan financial melalui hibah Program Pengabdian Pemula.

\section{Daftar Pustaka}

Cahyani, A. 2020. Motivasi Belajar Siswa SMA pada Pembelajaran Daring di Masa 
Pandemi Covid-19. Jurnal Pendidikan Islam. 3(1).

Febrianto, G.L., Sulton., dan Praherdiono, H. 2020. Pengembangan Media Video Pembelajaran untuk Pelatihan Instalasi Tenaga Listrik. Jurnal Kajian Teknologi Pendidikan, 3(2), 149- 157.

Resmini, S., Satriani, I., dan Rafi, M. 2021. Pelatihan Penggunaan Aplikasi Canva sebagai Media Pembuatan Bahan Ajar dalam Pembelajaran Bahasa Inggris. Abdimas Siliwangi, 4 (2): 335-343

Setiawan, B.A., dan Jatmikowati, T.E. 2021. Pelatihan Pengembangan Bahan Ajar Handout Berbasis Aplikasi Canva bagi Guru di SMA Baitul Arqom. Abdi Indonesia, 1(1):1-8

Sinsuw, A.A.E., dan Sambul, A.M. 2017. Pelatihan Pengembangan Media Pembelajaran Berbasis Teknologi Informasi Bagi GuruGuru SMP. Jurnal Teknik Elektro dan Komputer, 6(3), 105-110.

Tanjung, R.E., dan Faiza, D. 2019. Canva sebagai Media Pembelajaran pada Mata Pelajaran Dasar Listrik dan Elektronika. Jurnal Vokasional Teknik Elektronika dan Informatika, 7(2), 79-85.

Wartomo, W. 2016. Peran Guru dalam Pembelajaran Era Digital. Prosiding Temu Ilmiah Nasional Guru VII, (November). 